\title{
Kesempatan Investasi, Kebijakan Dividen dengan Firm Size sebagai Variabel Moderasi
}

\author{
Dewa Ayu Mirah Satya Dewi1 \\ Fakultas Ekonomi dan Bisnis \\ Universitas Udayana, Indonesia
}

\section{Anak Agung Gde Putu Widanaputra ${ }^{2}$ Fakultas Ekonomi dan Bisnis Universitas Udayana, Indonesia}

Surel : mirahstyad0607@gmail.com ABSTRAK

Kebijakan dividen merupakan salah satu fungsi keuangan terpenting perusahaan. Hal ini dikarenakan kebijakan dividen memiliki pengaruh terhadap pemangku kepentingan perusahaan, baik manajer maupun investor. Penelitian ini bertujuan untuk mengetahui pengaruh kesempatan investasi terhadap kebijakan dividen dengan Firm Size sebagai variabel moderasi. Penelitian ini dilakukan pada perusahaan manufaktur di Bursa Efek Indonesia periode 2015-2019. Populasinya dengan jumlah 142 perusahaan. Berdasarkan metode purposive sampling dan pengeluaran data outlier diperoleh sampel berjumlah 34 perushaan. Teknik analisis data yang digunakan adalah Moderated Regression Analysis. Hasil analisis menunjukkan bahwa Firm Size tidak memperlemah pengaruh kesempatan investasi terhadap kebijakan dividen. Hasil penelitian ini mendukung teori residual theory of dividend dan agency theory. Selain itu, hasil penelitian ini juga dapat menjadi pertimbangan perusahaan dalam menentukan kebijakan dividen dan membantu investor dalam menentukan keputusan investasi.

Kata Kunci: Kesempatan Investasi; Kebijakan Dividen; Firm Size.

\section{Investment Opportunities, Dividend Policy with Firm Size as Moderating Variable}

\section{ABSTRACT}

Dividend policy is one of the most important financial functions of a company. This is because the dividend policy has an influence on the company's stakeholders, both managers and investors. This study aims to determine the effect of investment opportunities on dividend policy with Firm Size as a moderating variable. This research was conducted on manufacturing companies on the Indonesia Stock Exchange for the 2015-2019 period. The population is 142 companies. Based on the purposive sampling method and the expenditure of outlierdata, a sample of 34 companies was obtained. The data analysis technique used is Moderated Regression Analysis. The results of the analysis show that Firm Size does not weaken the effect of investment opportunities on dividend policy. The results of this study support the residual theory of dividend and agency theory. In addition, the results of this study can also be considered by companies in determining dividend policy and assisting investors in making investment decisions.

Keywords: $\quad$ Investment Opportunity Set; Dividend Policy; Firm Size.

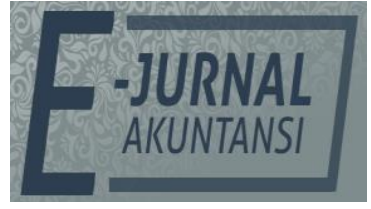

e-ISSN 2302-8556

Vol. 31 No. 12

Denpasar, Desember 2021

Hal. 3122-3132

10.24843/EJA.2021.v31.i12.p07

PENGUTIPAN:

Dewi, D. A. M. S. \&

Widanaputra, A. A. G. P.

(2021). Kesempatan Investasi, Kebijakan Dividen dengan

Firm Size sebagai Variabel

Moderasi. E-Jurnal Akuntansi,

31(12), 3122-3132

RIWAYAT ARTIKEL:

Artikel Masuk:

6 Mei 2021

Artikel Diterima: 24 Juli 2021

Artikel dapat diakses: https:/ / ojs.unud.ac.id/index.php/Akuntansi/index 


\section{PENDAHULUAN}

Pasar modal merupakan sebuah sarana yang dapat digunakan oleh perusahaan dalam menawarkan serta menjual efek perusahaannya kepada publik. Tujuan dilakukannya investasi di pasar modal adalah mengarahkan masyarakat untuk menanamkan dananya pada sektor-sektor yang lebih (Abi, 2016: 3). Embara et al. (2012) dalam Pradnyavita \& Suryanawa (2020) menyatakan bahwa tujuan investor berinvestasi di pasar modal adalah untuk memperoleh dividen atau capital gain. Gordon (1959) dan Lintner (1956) mengemukakan bahwa investor akan lebih menghargai return investasi yang berupa dividen daripada capital gain. Semakin tinggi dividen yang dibagikan, maka semakin baik pula kinerja perusahaan bagi para investor. Namun, tidak semua perusahaan membagikan dividen sebesar yang diinginkan oleh para pemegang saham. Jumlah dividen yang didistribusikan bergantung pada kebijakan dividen yang ditetapkan perusahaan dan besaran dividen yang akan dibayarkan diputuskan pada Rapat Umum Pemegang Saham (RUPS) (Nugraheni \& Mertha, 2019).

Kebijakan dividen merupakan sebuah kebijakan yang sangat penting dan berdampak cukup besar terhadap banyak pihak (Putri, 2017). Aini \& Sawitri (2020) menyatakan bahwa kebijakan dividen adalah sebuah kebijakan perusahaan dalam menempatkan keuntungan perusahaan, yang mana laba tersebut akan didistribusikan sebagai dividen atau ditahan sebagai laba ditahan untuk pembiayaan investasi baru (Zainudin et al., 2017). Hal tersebut dapat dilihat dari beberapa perusahaan di Bursa Efek Indonesia yang memperoleh laba yang tinggi namun mendistribusikan dividen dalam jumlah yang rendah. Selain itu, terdapat pula perusahaan yang memperoleh laba yang tidak terlalu tinggi namun membagikan dividen dalam jumlah yang tinggi kepada para investor. Berikut ini tabel dividen yang dibagikan oleh beberapa perusahaan manufaktur di Bursa Efek Indonesia tahun 2019.

Tabel 1. Dividen yang Dibagikan Perusahaan Manufaktur 2019 (dalam miliar rupiah)

\begin{tabular}{llcccc}
\hline No & \multicolumn{1}{c}{ Nama Perusahaan } & Total Aset & Laba & Dividen & Persentase \\
\hline 1. & PTEmdeki Utama Tbk. & 923 & 33 & 30 & $91 \%$ \\
2. & KMI Wire and Cable Tbk. & 3.556 & 395 & 32 & $8 \%$ \\
3. & PT Waskita Beton Precast Tbk. & 16.149 & 806 & 551 & $68 \%$ \\
4. & PT Industri Jamu dan Farmasi & 3.536 & 807 & 640 & $79 \%$ \\
& Sido Muncul Tbk & 16.015 & 817 & 300 & $37 \%$ \\
5. & Astra Otoparts Tbk. & 50.902 & 13.721 & 13.632 & $99 \%$ \\
6. & HMSampoerna Tbk & 351.958 & 26.621 & 10.202 & $38 \%$ \\
7. & PT Astra International Tbk & & & & \\
\hline
\end{tabular}

Sumber: Data Penelitian, 2021

Tabel 1 menunjukkan bahwa terdapat kesenjangan dalam pembagian dividen dari beberapa perusahaan tersebut. Hal tersebut mengindikasikan terdapat beberapa faktor yang memengaruhi perusahaan dalam membagikan dividen. Salah satu faktor yang yang diduga mampu memengaruhi kebijakan dividen dalam penelitian ini adalah kesempatan investasi.

Kesempatan investasi pada suatu perusahaan dapat memengaruhi kebijakan dividen (Wulandari \& Suardana, 2017). Kesempatan investasi dapat digunakan perusahaan sebagai pilihan investasi saat ini yang diharapkan mampu 
menghasilkan keuntungan yang lebih banyak di masa mendatang (Gaver \& Gaver, 1993). Suharli (2007) menyatakan bahwa apabila kondisi perusahaan sedang bagus, maka perusahaan akan cenderung melakukan penanaman modal baru daripada membayarkan dividen yang tinggi. Brigham \& Gapenski (1996) dalam Usman (2006) juga menyatakan bahwa pendanaan terhadap peluang investasi yang menguntungkan harus dilakukan terlebih dahulu sebelum dividen dibayarkan. Sehingga perusahaan yang memiliki kesempatan investasi yang besar akan mengurangi atau bahkan tidak membagikan dividen kepada para pemegang saham (Juhandi et al., 2019).

Selain karena adanya fenomena perbedaan dividen yang dibagikan perusahaan manufaktur pada tahun 2019, latar belakang penelitian ini juga disebabkan oleh adanya perbedaan hasil penelitian terdahulu. Hasil penelitian yang dilakukan oleh Yudiana \& Yadnyana (2016), Wulandari \& Suardana (2017), serta Chintya et al. (2018) menyatakan bahwa kesempatan investasi perusaahaan berpengaruh negatif terhadap kebijakan dividen. Sedangkan penelitian yang telah dilakukan oleh Deni et al. (2017), Putri (2017), serta Aini \& Sawitri (2020) menyatakan bahwa kesempatan investasi berpengaruh positif terhadap kebijakan dividen. Berbeda dengan penelitian yang dilakukan oleh Ariandani \& Yadnyana (2016), Pradana \& Sanjaya (2017), serta Palupi (2019) menyatakan bahwa kesempatan investasi yang dimiliki oleh perusahaan tidak memiliki pengaruh terhadap kebijakan dividen.

Hasil penelitian terdahulu memperoleh hasil yang inkonsisten mengenai pengaruh kesempatan investasi terhadap kebijakan dividen, maka peneliti menduga diperlukan variabel Firm Size yang mampu memoderasi hubungan kedua variabel tersebut. Menurut Arseto \& Jufrizen (2018) Firm Size merupakan sebuah cerminan total dari aset yang dimiliki perusahaan. Dalam Tabel 1. menunjukkan bahwa perbedaan ukuran perusahaan yang dilihat dari total asetnya, juga memengaruhi keputusan kebijakan dividen perusaahaan (Labhane \& Mahakud, 2016). Hal ini didukung dengan penelitian yang dilakukan oleh Lismawati \& Suryanto (2017), Arseto \& Jufrizen (2018), dan Idris et al. (2020) yang menemukan bahwa Firm Size sebagai variabel moderasi berpengaruh terhadap kebijakan dividen.

Berdasarkan residual theory of dividend, pendanaan terhadap peluang investasi yang menguntungkan harus dilakukan terlebih dahulu sebelum dividen dibayarkan (Brigham \& Gapenski, 1996 dalam Usman, 2006) dan pembayaran dividen dilakukan apabila masih terdapat arus kas sisa (Omar \& Echchabi, 2019). Hal tersebut dikarena perusahaan cenderung membiayai proyek investasi menggunakan dana internal (Bhagwat \& Debruine, 2009 dalam Yeo, 2018) daripada menggunakan dana eksternal karena lebih murah (Wulandari \& Suardana, 2017), sehingga manajemen akan memilih menahan laba untuk investasi dibandingkan membagikan dividen dalam jumlah yang tinggi. Keadaan ini akan menyababkan terjadinya konflik agensi (Jensen \& Meckling, 1976). Ukuran perusahaan yang besar akan membuat perusahaan lebih banyak menemukan peluang-peluang baru untuk melakukan investasi (Hashmi et al., 2020). Meskipun semakin besar ukuran perusahaan akan mempermudah perusahaan memperoleh modal eksternal, tetapi tidak dapat dipungkiri bahwa perusahaan tentu akan mengalokasikan dananya lebih banyak ke investasi 
dibandingkan ke pembagian dividen, sehingga dividen yang akan dibagikan kepada para pemegang saham akan semakin rendah.

$\mathrm{H}_{1}$ : Semakin besar kesempatan investasi yang dimiliki perusahaan, maka dividen yang akan dibagikan akan semakin kecil, terutama saat ukuran perusahaan besar.

\section{METODE PENELITIAN}

Penelitian ini meneliti bagaimana pengaruh kesempatan investasi terhadap kebijakan dividen dengan Firm Size sebagai variabel moderasi. Dalam penelitian ini dilakukan pendekatan kuantitatif berbentuk asosiatif. Lokasi penelitian dilakukan di perusahaan sektor manufaktur yang terdaftar di Bursa Efek Indonesia (BEI). Data penelitian diperoleh dengan mengakses laman resmi BEI di $w w w . i d x . c o . i d$. Objek penelitian ini yakni kebijakan dividen, kesempatan investasi dan Firm Size.

Kebijakan dividen merupakan keputusan perusahaan dalam menentukan jumlah dividen yang dibayarkan beserta besaran laba yang akan ditahan perusahaan dalam bentuk laba ditahan untuk kegiatan investasi (Mui \& Mustapha, 2016). Dalam penelitian ini kebijakan dividen diproksikan dengan Dividend Payout Ratio (DPR). Perhitungan kebijakan dividen dengan Dividen Payour Ratio (DPR) diformulasikan sebagai berikut (Yasmita \& Widanaputra, 2018).

Dividend Payout Ratio $=\frac{\text { Dividend Per Share }}{\text { Earning Per Share }}$

Kesempatan investasi adalah sebuah gabungan antara aset perusahaan dengan pilihan investasi di masa mendatang yang memiliki net present value positif (Myers, 1977). Dalam penelitian ini kesempatan investasi diproksikan dengan Market to Book Value of Equity (MVE/BVE). Untuk menghitung kesempatan investasi digunakan rumus sebagai berikut (Palupi, 2019).

$$
M B V E=\frac{\text { (Jumlah Saham Beredar } \times \text { Harga Saham Penutupan })}{\text { Total Ekuitas }} \text {. }
$$

Firm Size merupakan ukuran perusahaan yang dapat dilihat dari berasan total aset yang dimiliki perusahaan (Farooq \& Ahmed, 2019). Dalam penelitian ini Firm Size diproksikan dengan logaritma normal dari total aset. Firm Size diukur dengan logaritma normal dari total aset untuk mengurangi fluktuasi data yang berlebih karena besarnya nilai aset perusahaan. Untuk menghitung Firm Size dapat digunakan rumus sebagai berikut (Pradnyavita \& Suryanawa, 2020).

Firm Size $=$ Ln $($ Total Aset $)$.................................................. (3)

Dalam penelitian ini yang menjadi populasi adalah perusahaan manufaktur yang tercatat di Bursa efek Indonesia dalam periode 2015-2019 dengan total perusahaan sebanyak 142 perusahaan. Sampel dalam penelitian ini dipilih dengan teknik non-probability sampling dengan metode purposive sampling. Purposive sampling merupakan metode penentuan sampel yang dilakukan dengan pertimbangan atau kriteria tertentu (Indriantoro \& Supomo, 2018: 128). Adapun kriteria sampel dalam penelitian ini yakni: perusahaan yang mempublikasikan laporan keuangan secara berturut-turut selama periode 2015-2019; mempublikasikan laporan keuangannya dalam mata uang rupiah selama periode 2015-2019; tidak mengalami kerugian selama periode 2015-2019; membagikan dividen secara berturut-turut selama periode 2015-2019; serta memiliki 
kelengkapan data yang dibutuhkan peneliti.Sehingga diperoleh sampel penelitian sebanyak 34 perusahaan selama lima tahun penelitian.

Metode pengumpulan data yang digunakan dalam penelitian ini adalah metode observasi nonpartisipan, dengan jenis data berupa data kuantitatif dan sumber datanya berupa data sekunder. Adapun teknik analasis data yang digunakan adalah Moderated Regression Analysis (MRA) di mana dalam persamaan regresinya mengandung unsur interaksi. Persamaan uji Moderated Regression Analysis dinyatakan sebagai berikut.

$Y=\alpha+\beta_{1} X_{1}+\beta_{2} X_{2}+\beta_{3} X_{1} X_{2}+\varepsilon$

Keterangan:

$$
\begin{array}{ll}
\mathrm{Y} & =\text { Variabel Independen (Kebijakan Dividen) } \\
\mathrm{a} & =\text { Konstanta } \\
\beta_{1}, \beta_{2}, \beta_{3}, & =\text { Nilai Koefisien Regresi Berganda } \\
\mathrm{X}_{1} & =\text { Kesempatan Investasi } \\
\mathrm{X}_{2} & =\text { Firm Size } \\
\mathrm{X}_{1} \mathrm{X}_{2} & =\text { Interaksi antara Kesempatan Investasi dengan Firm Size } \\
\varepsilon &
\end{array}
$$

\section{HASIL DAN PEMBAHASAN}

Sampel penelitian yang terdiri dari 34 perusahaan dengan keseluran sampel sebanyak 170 sampel pengamatan diperoleh dari proses seleksi sampel penelitian berikut.

\section{Tabel 2. Hasil Seleksi Sampel Penelitian}

\begin{tabular}{llr}
\hline No. & \multicolumn{1}{c}{ Keterangan } & Jumlah \\
\hline & $\begin{array}{l}\text { Perusahaan sektor manufaktur yang terdaftar di Bursa Efek Indonesia } \\
\text { selama periode 2015-2019. }\end{array}$ & 142 \\
1. & $\begin{array}{l}\text { Perusahaan sektor manufaktur yang tidak mempublikasikan laporan } \\
\text { keuangan tahunan secara berturut-turut selama periode 2015-2019. }\end{array}$ \\
2. $\quad \begin{array}{l}\text { Perusahaan sektor manufaktur yang tidak mempublikasikan laporan } \\
\text { keuangan dalam mata uang Rupiah selama periode 2015-2019. }\end{array}$ & $(29)$ \\
3. $\quad \begin{array}{l}\text { Perusahaan sektor manufaktur yang mengalami kerugian selama } \\
\text { periode2015-2019. }\end{array}$ & $(5)$ \\
4. $\quad \begin{array}{l}\text { Perusahaan sektor manufaktur yang tidak membagikan dividen } \\
\text { selama tahun 2015-2019. }\end{array}$ & $(64)$ \\
5. & $\begin{array}{l}\text { Perusahaan sektor manufktur yang tidakmemiliki kelengkapan data } \\
\text { mengenai variabel-variabel yang diteliti dalam penelitian. }\end{array}$ \\
& $\begin{array}{l}\text { Jumlah perusahaan yang terpilih sebagai sampel. } \\
\text { Jumlah data outlier. }\end{array}$ \\
& $\begin{array}{l}\text { Jumlah sampel terseleksi. } \\
\text { Jumlah sampel selamalima tahun pengamatan. }\end{array}$ \\
\hline
\end{tabular}
Sumber: Data Penelitian, 2021

Analisis statistik deskkriptif memberikan informasi mengenai variabelvariabel yang terdapat dalam penelitian yang mencangkup nilai ekstrim berupa nilai maksimum dan minum, nilai rata-rata (mean), serta standar deviasi dari tiaptiap variabel. 
Tabel 3. Hasil Uji Statistik Deskriptif

\begin{tabular}{lccccc}
\hline \multicolumn{1}{c}{ Variabel } & $\mathrm{N}$ & Minimum & Maksimum & Mean & Standar Deviasi \\
\hline DPR & 170 & 0,060 & 1,218 & 0,413 & 0,222 \\
MBVE & 170 & 0,213 & 6,857 & 2,203 & 1,627 \\
SIZE & 170 & 26,016 & 33,495 & 28,973 & 1,716 \\
Valid N & 170 & & & & \\
(listwise) & & & & & \\
\hline
\end{tabular}

Sumber: Data Penelitian, 2021

Variabel kebijakan dividen pada penelitian ini memiliki nilai minimum sebesar 0,060 ditunjukan oleh Sepatu Bata Tbk. pada tahun 2015. Nilai maksimum sebesar 1,218 ditunjukkan oleh Jembo Cable Company Tbk. pada tahun 2015. Dengan nilai mean sebesar 0,413 dan standar deviasi bernilai 0,222.

Kesempatan investasi dalam penelitian ini memiliki nilai minimum sebesar 0,213 ditunjukkan oleh Ricky Putra Globalindo Tbk. pada tahun 2019. Sedangkan nilai maksimumnya sebesar 6,857 ditunjukkan oleh Mayora Indah Tbk. pada tahun 2018. Nilai mean yakni 2,203 dengan standar deviasi bernilai 1,627.

Firm Size dalam penelitian ini memiliki nilai minimum sebesar 26,016 ditunjukkan oleh Ateliers Mecaniques D'Indonesie pada tahun 2019. Nilai maksimumnya yakni 33,495 ditunjukkan oleh Astra International Tbk. pada tahun 2019. Nilai mean yakni 28,973 dengan standar deviasi bernilai 1,716.

Penelitian ini melalui pengujian asumsi klasik dengan tujuan untuk menyakinkan serta memastikan bahwa model regresi telah memenuhi semua asumsi dasar analisis regresi. Dalam penelitian ini data ditansformasikan kedalam bentuk logaritma normal untuk mangatasi data yang tidak lolos uji asumsi klasik. Tabel 4. Hasil Uji Normalitas

\begin{tabular}{lc}
\hline & Unstandardized Residual \\
\hline $\mathrm{N}$ & 170 \\
Asymp.Sig (2-tailed) & 0,274 \\
\hline
\end{tabular}

Sumber: data penelitian, 2021

Uji normalitasi dalam penelitian dilakukan dengan uji One-Sample Kolmogorov Smirnov. Berdasarkan Tabel 4, diperoleh nilai signifikansi 0,274 lebih besar dari 0,05, yang berarti data penelitian ini telah berdistribusi normal.

Tabel 5. Hasil Uji Autokorelasi

\begin{tabular}{ccccccc}
\hline $\mathrm{n}$ & $\mathrm{k}$ & $\mathrm{DU}$ & $\mathrm{DL}$ & $\mathrm{DW}$ & Kriteria & Keterangan \\
\hline 170 & 3 & 1,773 & 1,725 & 1,930 & DU<DW $<4-\mathrm{DU}$ & $\begin{array}{c}\text { Tidak terdapat gejala } \\
\text { autokorelasipositif atau } \\
\text { pun negatif }\end{array}$ \\
\hline
\end{tabular}

Sumber: Data Penelitian2021

Uji autokorelasi dalam penelitian ini dilakukan dengaan uji Cochrane Orcutt. Dalam pengujian ini data ditansformasikan terlebih dahulu kedalam bentuk Lag sebelum dilakukan pengujian Durbin-Watson. Berdasarkan Tabel 5, diperoleh nilai DW sebesar 1,930 dengan n sebanyak 170 observasi dan $\mathrm{k}=3$. Kriteria pengujian yakni $\mathrm{DU}<\mathrm{DW}<4$-DU $(1,773<1,930<2,227)$ terpenuhi, dengan demikian dapat disimpulkan bahwa dalam model regresi ini tidak terjadi gelaja autokorelasi. 
Tabel 6. Hasil Uji Multikolinearitas

\begin{tabular}{|c|c|c|c|}
\hline \multirow{2}{*}{ Variabel } & \multicolumn{2}{|c|}{ Collinearity Statistic } & \multirow{2}{*}{ Keterangan } \\
\hline & Tolerance & VIF & \\
\hline$\overline{M B V E}$ & 0,864 & 1,157 & Bebas Multikolinearitas \\
\hline SIZE & 0,864 & 1,157 & Bebas Multikolinearitas \\
\hline
\end{tabular}

Sumber: Data Penelitian, 2021

Uji multikolinearitas dalam penelitian ini dilakukan dengan menguji korelasi antar variabel bebasnya. Berdasarkan Tabel 6, diperoleh nilai tolerance dari masing-masing variabel lebih besar dari 0,10. Sedangkan nilai VIF untuk kedua variabel tersebut lebih kecil dari 10. Sehingga dapat disimpulkan bahwa model regresi dalam penelitian ini bebas gejala multikolinearitas.

Tabel 7. Hasil Uji Heteroskedastisitas

\begin{tabular}{lcc}
\hline Variabel & Sig. & Keterangan \\
\hline MBVE & 0,936 & Bebas Heteroskedastisitas \\
SIZE & 0,061 & Bebas Heteroskedastisitas \\
MBVE.SIZE & 0,764 & Bebas Heteroskedastisitas \\
\hline
\end{tabular}

Sumber: Data Penelitian, 2021

Uji heteroskedastisitas dalam penelitian ini dilakukan dengan uji Glejser. Berdasarkan Tabel 7, diperoleh nilai signifikansi untuk setiap variabel bebas lebih besar dari 0,05. Dengan demikian model regresi pada penelitian ini terbebas dari gejala heteroskedastisitas.

Tabel 8. Hasil Uji Moderated Regression Analysis

\begin{tabular}{lrrrrr}
\hline \multirow{1}{*}{ Model } & \multicolumn{2}{c}{ Unstandardized } & \multicolumn{2}{c}{$\begin{array}{c}\text { Standardized } \\
\text { Coefficients }\end{array}$} & \multicolumn{2}{c}{ Coefficients } & & \multirow{2}{*}{ Sig. } \\
\cline { 2 - 4 } & \multicolumn{1}{c}{ B } & Std. Error & Beta & & \\
\hline (Constant) & 3,206 & 2,026 & & 1,583 & 0,115 \\
MMBVE & $-1,792$ & 0,181 & $-2,595$ & $-9,890$ & 0,000 \\
SIZE & $-1,589$ & 0,616 & $-0,161$ & $-2,573$ & 0,011 \\
MBVE.SIZE & 1,155 & 0,138 & 2,223 & 8,356 & 0,000 \\
Adjusted RSquare & & & & & 0,453 \\
F Hitung & & & & & 47,713 \\
SignifikansiF & & & & & 0,000 \\
\hline
\end{tabular}

Sumber: data Penelitian, 2021

Hasil dari pengujian moderated regression analysis (Tabel 8), diperoleh persamaan model regresi sebagai beritkut.

$Y=3,206-1,792 M B V E-1,586 S I Z E+1,155 M B V E . S I Z E+\varepsilon$

Nilai konstanta sebesar 3,206 menunjukkan bahwa apabila kesempatan investasi, Firm Size, dan interaksi antara kesempatan investasi dan Firm Size memiliki nilai nol, maka kebijakan dividen akan bernilai 3,206. Variabel kesempatan investasi (MBVE) memiliki koefisien bernilai negatif sebesar 1,792, yang berarti apabila kesempatan investasi meningkat satu satuan, maka kebijakan dividen akan menurun sebesar 1,792 satuan dengan asumsi nilai variabel lainnya konstan. Variabel Firm Size (SIZE) memiliki koefisien bernilai negatif sebesar1,586, memiliki arti apabila Firm Size meningkat satu satuan, maka kebijakan dividen akan menurun sebesar 1,586 satuan dengan asumsi variabel lainnya bernilai konstan. Interaksi antara variabel kesempatan investasi dengan Firm Size (MBVE.SIZE) memiliki koefisien bernilai positif sebesar 1,155, menunjukkan apabila moderasi Firm Size meningkat satu satuan, maka pengaruh kesempatan 
investasi pada kebijakan dividen akan meningkat sebesar 1,155 dengan asumsi variabel lainnya memiliki nilai yang konstan.

Koefisien determinasi pada model regresi linear dengan moderasi dilihat dari nilai adjusted $R$ square. Dalam Tabel 8, nilai adjusted $R$ square memiliki nilai 0,453 yang berarti $45,3 \%$ variasi dari kebijaan dividen mampu dijelaskan oleh kesempatan investasi, Firm Size, dan interaksi kesempatan investasi dengan Firm Size. Sisanya sebesar $54,7 \%$ dijelaskan oleh variabel lain yang tidak terdapat dalam penelitian. Uji kelayakan model dilakukan dengan uji F. Model regresi dikatakan layak apabila signifikansi uji $\mathrm{F}$ p-value bernilai lebih kecil dari 0,05. Tabel 8 . menunjukkan nilai signifikansi sebesar 0,000 lebih kecil dari 0,05 , sehingga model regresi dalam penelitian ini layak untuk digunakan.

Hipotesis satu dalam penelitian menyatakan bahwa semakin besar kesempatan investasi yang dimiliki perusahaan, maka dividen yang akan dibagikan akan semakin kecil, terutama saat ukuran perusahaan besar. Berdasarkan Tabel 8, diperoleh signifikansi variabel interaksi kesempatan investasi dengan Firm Size sebesar 0,000 lebih kecil daripada 0,05 dengan koefisien regresi yakni 1,155. Koefisien regresi variabel interaksi kesempatan investasi dan Firm Size memiliki nilai positif, sedangkan koefisien regresi variabel kesempatan investasi bernilai negatif. Hal tersebut memiliki arti bahwa Firm Size tidak dapat memperlemah hubungan antara kesempatan investasi dengan kebijakan dividen. Dengan demikian hipotesis satu $\left(\mathrm{H}_{1}\right)$ ditolak.

Hasil dalam penelitian ini menjelaskan bahwa apabila kesempatan investasi perusahaan tinggi, maka perusahaan tidak akan mengurangi distribusi dividen, terutama saat ukuran perusahaan tersebut besar. Hal tersebut mungkin dikarenakan perushaan besar biasanya memiliki cadangan laba yang cukup untuk melakukan investasi kembali. Dengan demikian meskipun kesempatan investasi yang dimiliki perusahaan tinggi, maka proporsi pembagian dividen kepada pemegang saham tidak akan dikurangkan. Sebaliknya, ketika perusahaan berukuran kurang besar, perusahaan cenderung akan mendistribusikan dividen dalam jumlah yang tidak tinggi meskipun kesempatan investasi dari perusahaan tersebut rendah. Keadaan ini mungkin disebabkan oleh ketersediaan dana yang dimiliki oleh perusahaan tersebut tidak sebanyak perusahaan besar.

Hasil penelitian ini sejalan dengan penelitian yang telah dilakukan oleh Lismawati \& Suryanto (2017) yang menyatakan bahwa ukuran perusahaan yang besar akan memiliki kekuatan financial, Brav et al. (2005) dalam Harakeh (2020) yang menyatakan bahwa manajer enggan memotong dividen untuk kepentingan investasi, serta Myers \& Majluf (1984) yang menyatakan bahwa perusahaan besar akan membayar dividen lebih besar untuk mengurangi terjadinya agency problem. Sehingga, meskipun kesempatan investasi yang dimiliki oleh perusahaan tinggi, perusahaan belum tentu mengurangi proporsi dividen yang akan didistribusikan kepada para pemegang saham. Hasil penelitian ini mengonfirmasi residual theory of dividend yang menyatakan bahwa perusahaan dapat membagikan dividen kepada pemegang saham apabila perusahaan masih memiliki dana setelah dilakukan pembiayaan untuk proyek investasi. Selain itu juga mengonfirmasi agency theory yang menyatakan bahwa perusahaan akanlebih memilih untuk tetap membagikan dividen walaupun dalam jumlah yang rendah untuk mengurangi agency cost yang diakibatkan oleh agency problem. 


\section{SIMPULAN}

Hasil penelitian ini menunjukkan bahwa Firm Size tidak memperlemah hubungan pengaruh kesempatan investasi pada kebijakan dividen. Hal ini berarti semakin tinggi kesempatan investasi perusahaan, didukung dengan ukuran perusahaan yang besar, maka proporsi dividen yang akan didistribusikan tidak akan dikurangkan karena ketersediaan dana yang cukup untuk membayar dividen.

Adapun beberapa saran yang dapat diberikan terkait hasil penelitian ini adalah bagi perusahaan diharapkan dapat mempertimbangkan setiap keputusan keuangan karena salah satu tujuan investor berinvestasi adalah untuk mendapatkan dividen, serta untuk menghindari terjadinya konflik agensi antara manajemen serta para investor. Bagi investor dapat memerhatikan variabel lain selain Firm Size. Hal tersebut dikarenakan Firm Size tidak memperlemah pengaruh kesempatan investasi terhadap kebijakan dividen. Bagi peneliti selanjutnya disarankan agar tidak hanya menggunakan variabel yang terdapat dalam penelitian ini, tetapi juga menggunakan variabel lain serta dapat menggunakan objek penelitian lain diluar perusahaan manufaktur untuk mengoptimalkan hasil penelitian.

\section{REFERENSI}

Abi, P. P. (2016). Semakin Dekat dengan Pasar Modal. Yogyakarta: Deepublish.

Aini, S. N., \& Sawitri, A. P. (2020). Dampak Sales Growth, Posisi Kas, Investment Opportunity Set, Kepemilikan Institusional terhadap Kebijakan Dividen Pada Indeks Kompas 100. Majalah Ekonomi, 25(1411), 36-42.

Ariandani, P., \& Yadnyana, I. (2016). Likuiditas Memoderasi Pengaruh Profitabiltas Dan Investment Opportunity Set (Ios) Pada Kebijakan Dividen. E-Jurnal Akuntansi, 17(1), 615-634.

Arseto, D. D., \& Jufrizen, J. (2018). Pengaruh Return On Asset dan Current Ratio Terhadap Dividen Payout Ratio Dengan Firm Size Sebagai Variabel Moderating. Jurnal Ilmiah Magister Manajemen, 1(1), 15-30.

Bhagwat, Y., \& Debruine, M. (2009). Impact of EBITDA on Capital Expenditures in the Shipping Industry. IJGMSQ, 1, 22-31.

Brav, A., Graham, J. R., Harvey, C. R., \& Michaely, R. (2005). Payout policy in the 21st century. Journal of Financial Economics, 77(3), 483-527. https:/ / doi.org/10.1016/j.jfineco.2004.07.004

Brigham, E. F., \& Gapenski, L. C. (1996). Intermediate Financial Management. Florida: The Dryden Press.

Chintya, N. M., Theodora, N., Evelyn, V., \& Huda, A. N. (2018). Analisis Pengaruh Tingkat Profitabilitas dan Kesempatan Investasi Perusahaan Terhadap Kebijakan Pembagian Dividen. Jurnal Riset Akuntansi \& Keuangan, 6(2), 161172. https:// doi.org/10.17509/jrak.v6i2.11635

Deni, F. F., Aisjah, S., \& Djazuli, A. (2016). Analisis Variabel-Variabel yang Mempengaruhi Kebijakan Dividen (Studi pada Perusahaan Manufaktur yang Terdaftar di Bursa Efek Indonesia) Febrianto Frans. Jurnal STEI Ekonomi, 14(2), 359-365. https:// doi.org/10.36406/jemi.v26i2.224

Embara, C. T. D. L., Wiagustini, N. L. P., \& Badjra, I. B. (2012). Variabel-Variabel yang Berpengaruh terhadap Kebijakan Dividen serta Harga Saham pada 
Perusahaan Manufaktur di Bursa Efek Indonesia. Matrik:Jurnal Manajemen, Strategi Bisnis dan Kewirausahaan, 6(2), 119-129. https:/ / doi.org/10.24843/MATRIK:JMBK

Farooq, O., \& Ahmed, N. (2019). Dividend policy and political uncertainty: Evidence from the US presidential elections. Research in International Business and Finance, 48(May 2018), 201-209. https:/ / doi.org/10.1016/j.ribaf.2019.01.003

Gaver, J. J., \& Gaver, K. M. (1993). Additional Evidence on the Association between the Invesment Opportunity Set and Corporate Financing, Dividend, and Compensation Policies. Journal of Accounting and Economics, 16(1), 125-160. https:/ / doi.org/http:/ / dx.doi.org/10.1016/0165-4101(93)90007-3

Gordon, M. J. (1959). DIvidends, Earnings, and Stock Price. The Review of Economics and Statistics, 41(2), 99-105. https://doi.org/ doi:10.2307/1927792

Harakeh, M. (2020). Dividend policy and corporate investment under information shocks. Journal of International Financial Markets, Institutions and Money, 65(xxxx), 101184. https://doi.org/10.1016/j.intfin.2020.101184

Hashmi, S. D., Gulzar, S., Ghafoor, Z., \& Naz, I. (2020). Sensitivity of Firm Size measures to practices of corporate finance: evidence from BRICS. Future Business Journal, 6(1). https://doi.org/10.1186/ s43093-020-00015-y

Idris, A. A., Bala, H., \& Ekundayo, O. (2020). Does size of the firm matter in the relationship between foreign ownership and dividend policy? Malaysian Management Journal, 24(July), 1-18.

Indriantoro, N., \& Supomo, B. (2018). Metodologi Penelitian Bisnis untuk Akuntansi dan Manajemen. Yogyakarta: Penerbit Andi.

Jensen, M. C., \& Meckling, W.H. (1976). Theory of theFirm: Managerianl Behavior, Acency Costs and Ownership Structure. Journal of Financial Economics, 3(4), 305-360. https://doi.org/10.1177/0018726718812602

Juhandi, N., Fahlevi, M., Abdi, M. N., \& Noviantoro, R. (2019). Liquidity, Firm Size and Dividend Policy to the Value of the Firm (Study in Manufacturing Sector Companies Listed on Indonesia Stock Exchange). Business and Management Research, 100(Icoi), 313-317. https:/ /doi.org/10.2991/icoi-19.2019.53

Labhane, N. B., \& Mahakud, J. (2016). Determinants of Dividend Policy of Indian Companies. Paradigm, 20(1), 36-55. https:/ / doi.org/10.1177/0971890716637698

Linda Yasmita, N. P., \& Widanaputra, A. A. G. P. (2018). Pengaruh Asimetri Informasi Pada Kebijakan Dividen Dengan Investment Opportunity Set Sebagai Variabel Pemoderasi. E-Jurnal Akuntansi, 22(3), 2040-2064. https:/ / doi.org/10.24843/eja.2018.v22.i03.p15

Lintner J. (1956). Distribution of Incomes of Corporations Among Dividends, Retained Earnings, and Taxes. The American Economic Review, 46(2), 97-113.

Lismawati, L., \& Suryanto. (2017). Faktor - Faktor Yang Mempengaruhi Kebijakan Dividen: Ukuran Perusahaan Sebagai Pemoderasi. Jurnal Bisnis Dan Akuntansi, 19(5), 365-374.

Mui, Y. T., \& Mustapha, M. (2016). Determinants of Dividend Payout Ratio: Evidence from Malaysian Public Listed Firms. Journal of Applied Environmental and Biological Sciences, 6(1), 48-54.

Myers, S. C. (1977). Determinants of Corporate Borrowing. Journal of Financial 
Economics, 5(1), 147-175. https:/ / doi.org/10.1253/circj.CJ-16-0846

Myers, S. C., \& Majluf, N.S. (1984). Corporate financing and investment decisions when firms have information that investors do not have. Journal of Financial Economics, 13(2), 187-221. https:/ / doi.org/10.1016/0304-405X(84)90023-0

Nugraheni, N. P., \& Mertha, M. (2019). Pengaruh Likuiditas Dan Kepemilikan Institusional Terhadap Kebijakan Dividen Perusahaan Manufaktur. E-Jurnal Akuntansi, 26(1), 736-762 https:// doi.org/10.24843/ eja.2019.v26.i01.p27

Omar, M. M. S., \& Echchabi, A. (2019). Dividend Policy and payout practices in Malaysia: A qualitative analysis. Journal of Accounting Finance and Auditing Studies (JAFAS), 5(1), 226-240. https://doi.org/10.32602/jafas.2019.11

Palupi, A. R. A. (2019). Pengaruh Kepemilikan Institusional,Ukuran Perusahaan, Likuiditas, dan Investment Opportunity Set terhadap Kebijakan Dividen pada Perusahaan Pertambangan yang Terdaftar di Bursa Efek Indonesia Periode 2014-2018. Jurnal Akuntansi Dan Keuangan. 1-17.

Pradana, S. W. L., \& Sanjaya, I. P. S. (2017). Dampak Profitabilitas, Aliran Kas Bebas, dan Kesempatan Investasi terhadap Pembayaran Dividen Perusahaan Perbankan. Jurnal Keuangan Dan Perbankan, 21(1), 113-124. https:/ / doi.org/10.26905/jkdp.v21i1.1232

Pradnyavita, K. I., \& Suryanawa, I. K. (2020). Pengaruhn Profitabilitas, Ukuran Perusahaan, dan Arus Kas Bebas terhadap Kebijakan Dividen. E-Jurnal Akuntansi, 30(1), 238-250. https:// doi.org/10.24843/EJA.2020.v30.i01.p18

Putri, A. R. (2017). Pengaruh Kebijakan Hutang, Profitabilitas, Likuiditas dan Kesempatan Investasi Terhadao Kebijakan Dividen. Jurnal Ilmu Dan Riset Akuntansi, 6(6), 1-476. https:/ / doi.org/10.1017/CBO9781107415324.004

Suharli, M. (2007). Pengaruh Profitability dan Investment Opportunity Set terhadap Kebijakan Dividen Tunai dengan Likuiditas Sebagai Variabel Penguat (Studi pada Perusahaan yang Terdaftar di Bursa Efek Jakarta. Jurnal Akuntansi Dan Keuangan, 9(1), 9-17. https:/ /doi.org/10.9744/jak.9.1.pp.9-17

Usman, B. (2006). Keinformatifan Harga Saham dalam Kaitannya dengan Efisiensi Investasi. Media Riset Manajemen E Bisnis, 6(3), 213-232.

Wulandari, D. U., \& Suardana, K. A. (2017). Pengaruh Profitabilitas, Kesempatan Investasi, Free Cash Flow, Dan Debt Policy Pada Kebijakan Dividen Perusahaan Manufaktur. E-Jurnal Akuntansi, 20(1), 202-230.

Yeo, H. J. (2018). Role of free cash flows in making investment and dividend decisions: The case of the shipping industry. Asian Journal of Shipping and Logistics, 34(2), 113-118. https:/ / doi.org/10.1016/j.ajs1.2018.06.007

Yudiana, I., \& Yadnyana, I. (2016). Pengaruh Kepemilikan Manajerial, Leverage, Investment Opportunity Set Dan Profitabilitas Pada Kebijakan Dividen Perusahaan Manufaktur. E-Jurnal Akuntansi, 15(1), 111-141.

Zainudin, R., Mahdzan, N. S., \& Yet, C. H. (2017). Dividend policy and stock price volatility of industrial products firms in Malaysia. International Journal of Emerging Markets, 34(1), 1-21. https: //Doi.org/10.1108/IJoEM-09-2016-0250 